Fitriana, Maswati Baharuddin, dan Sappe Wali Isolasi dan Identifikasi Bakțeri Pendegradasi Fenol yang Bersumber dari Danau Tempe Kabupaten Wajo Sulawesi Selatan

\title{
ISOLASI DAN IDENTIFIKASI BAKTERI PENDEGRADASI FENOL YANG BERSUMBER DARI DANAU TEMPE KABUPATEN WAJO SULAWESI SELATAN
}

\author{
Fitriana, Maswati Baharuddin, dan Sappe Wali \\ Jurusan Kimia, Fakultas Sains dan Teknologi, UIN Alauddin Makassar \\ Email: yanrafitriana@gmail.com
}

\begin{abstract}
Water pollution in Tempe Lake was consequence by people activity in around of Tempe Lake, such as domestic waste and agriculture waste. One of the dangerous pollutions which was resulted from the waste was phenol pollution. Phenol waste reduction efforts on Tempe Lake could be solved by biodegradation process using bacteria. This research aimed to: 1) Get the bacteria which was able to degrade phenol on samples sourced from Tempe Lake, Wajo South Sulawesi and 2) Identify the type of bacteria that can degrade phenol sourced from Lake Tempe, Wajo South Sulawesi. The Metods used in the research was making of media, isolation and purification of bacteria, identification of bacteria and testing the ability of phenol degradation. Bacterial identification tests include staining gram and biochemical tests (TSIA, SIM, MR-VP, urea, citric and sugar fermentation). The degradation test was performed using UV-Vis spectrophotometry with colorimetric method using follin reagent. The results showed that the bacterial identified as the genus Enterobacter spp and Klebsella spp which were gram negative bacteria. Test of phenol degradation at 48 hour incubation using UV-Vis shows that bacterial isolates $C_{1} F$ was able to degrade phenol 500 ppm to 3,091 ppm, bacterial isolate $S_{1} F$ was able to degrade phenol 500 ppm to 5,1153 ppm and bacterial isolate $\mathrm{H}_{2} \mathrm{~F}$ was able to degrade phenol 500 ppm to 7,7834 ppm.
\end{abstract}

Keywords: Degradation of phenol, Enterobacter sp., Klebsiella spp., Tempe Lake

\section{PENDAHULUAN}

Danau tempe adalah salah satu danau besar yang terletak di Propinsi Sulawesi Selatan, tepatnya di Kabupaten Wajo (70\%), Kabupaten Sidrap dan Kabupaten Soppeng. Danau tempe termasuk salah satu dari 15 danau di Indonesia yang tercemar. Permasalahan ekosistem danau tempe terdiri dari Kerusakan Daerah Tangkapan Air (DTA), kerusakan sempadan dan pencemaran perairan. Pencemaran yang terjadi pada Danau Tempe disebabkan oleh buangan limbah domestik, pertanian, pemukiman dan sisa pakan ikan. Hal ini menyebabkan terjadinya eutrofikasi pada permukaan air danau (Kementrian Lingkungan Hidup Republik Indonesia, 2011). 
Air limbah adalah air buangan dari masyarakat, rumah tangga, industri, air tanah, air permukaan serta buangan lainnya. Di dalam limbah cair terkandung zat-zat pencemar dengan konsentrasi tertentu yang bila dimasukkan ke bahan air dapat mengubah kualitas airnya. Kualitas air merupakan pencerminan kandungan konsentrasi makhluk hidup, energi, zat-zat, atau komponen lain yang ada dalam air. Limbah cair mempunyai efek negatif bagi lingkungan karena mengandung zat-zat beracun yang mengganggu keseimbangan lingkungan dan kehidupan makhluk hidup yang terdapat di dalamnya (Milasari dan Sukma, 2010).

Pencemaran air merupakan salah satu bentuk kerusakan lingkungan pada daerah perairan, termasuk di daerah perairan Danau Tempe sendiri. Pencemaran air itu sendiri didefinisikan sebagai masuknya atau dimasukkannya makhluk hidup, zat, energi dan atau komponen lain ke dalam air oleh kegiatan manusia, sehingga kualitas air turun sampai ke tingkat tertentu yang menyebabkan air tidak dapat berfungsi sesuai dengan peruntukkannya. Masukan tersebut sering disebut dengan istilah unsur pencemar (polutan) yang pada prakteknya masukan tersebut berupa buangan yang bersifat rutin (Yuliastuti, 2011).

Salah satu pencemaran air yang berbahaya bagi ekosistem hayati di Danau Tempe adalah pencemaran fenol. Sebagaimana yang kita ketahui bahwa fenol merupakan senyawa yang bersifat toksik dan mudah larut dalam air sehingga senyawa tersebut dan turunannya mudah menimbulkan pencemaran di alam. Selain itu, fenol memberi dampak gangguan kesehatan yaitu, antara lain iritasi paru-paru, kejang otot, kehilangan koordinasi, luka pada hati, ginjal, jantung, menimbulkan kanker, melepuhkan dan membakar kulit, bahkan dapat menyebabkan kematian. Dampak negatif adanya fenol dan turunannya dalam badan air sungai menyebabkan penyimpangan reproduksi pada zooplankton dan invertebrata yang merupakan kelompok sumber makanan dari ikan dan dapat menyebabkan kerusakan genetik dan gangguan sistem imun kekebalan tubuh pada ikan, sehingga dapat menjadi penyebab kematian pada ikan (Nurbaeti, 2014).

Berdasarkan hasil analisa laboratorium Air Pusarpedal (2006), konsentrasi fenol pada perairan danau tempe pada empat lokasi pengambilan sampel, yaitu pada lokasi pertama $<0,02 \mathrm{mg} / \mathrm{L}$, lokasi kedua (tengah danau) $<0,02 \mathrm{mg} / \mathrm{L}$, lokasi ketiga (pinggir danau) $<0,02 \mathrm{mg} / \mathrm{L}$ dan lokasi keempat $<0,02 \mathrm{mg} / \mathrm{L}$ menunjukkan bahwa pencemaran fenol telah melebihi ambang batas baku mutu air kelas I dan kelas II yaitu 0,001 mg/L (Kementrian Lingkungan Hidup Republik Indonesia, 2011). 
Salah satu alternatif potensial untuk mengolah limbah adalah dengan proses fotokatalis, filtrasi/penyaringan, teknik ozonasi, fitoremediasi dan degradasi fenol dengan bantuan mikroba. Penggunaan mikroba dalam mengatasi pencemaran fenol di lingkungan dimungkinkan sangat potensial. Hal tersebut disebabkan banyaknya lingkungan yang tercemar fenol, sehingga banyak mikroba yang menggunakan fenol sebagai sumber karbon tunggal dan sumber energi baik secara anaerob maupun aerob. Kelebihan penggunaan bakteri dalam proses degradasi fenol adalah bakteri mempunyai kemampuan menyesuaikan diri yang besar terhadap lingkungan. Selain itu bakteri ini juga tidak memerlukan tempat yang besar untuk tumbuh, sehingga mudah ditumbuhkan dalam media buatan dan tingkat pembiakannya relatif cepat ('Ulya, 2012).

Berdasarkan pemaparan di atas, maka dilakukan penelitian yang bertujuan untuk mengisolasi bakteri dari air Danau Tempe yang mampu mendegradasi fenol, sehingga dapat menjadi alternatif dalam mengatasi masalah pencemaran.

\section{Tujuan}

Tujuan penelitian untuk mengetahui:

1. Mengisolasi bakteri yang dapat mendegradasi fenol pada sampel yang bersumber dari Danau Tempe Kabupaten Wajo Sulawesi Selatan.

2. Mengidentifikasi jenis bakteri yang dapat mendegraasi fenol yang bersumber dari Danau Tempe Kabupaten Wajo Sulawesi Selatan.

\section{METODE PENELITIAN}

\section{Alat}

Alat-alat yang digunakan pada penelitian ini adalah tabung reaksi, botol sampel, erlenmeyer, gelas ukur, rak tabung, cawan petri, beker gelas, timbangan analitik, oven, autoklaf, mikroskop, lampu bunsen, gelas objek, spektrofotometer UV-VIS, jarum ose, pipet tetes, cuvet, batang pengaduk, botol semprot, tabung durham, pipet tip, pipet mikro dan shaker, sentrifuge, micro cube, tabung sentrifuge, incubator, laminar air flow, lemari asam, labu takar, dan kompor listrik .

\section{Bahan}

Bahan yang digunakan dalam penelitian ini adalah sampel air yang diambil dari Danau Tempe Kab. Wajo, aqua destilasi, spiritus, ammonium nitrat $\left(\mathrm{NH}_{4} \mathrm{NO}_{3}\right)$, kalium dihidro posfat $\left(\mathrm{KH}_{2} \mathrm{PO}_{4}\right)$, dikalium hidro posfat 
Fitriana, Maswati Baharuddin, dan Sappe Wali Isolasi dan Identifikasi Bakteri Pendegradasi Fenol yang Bersumber dari Danau Tempe Kabupaten Wajo Sulawesi Selatan

( $\left.\mathrm{K}_{2} \mathrm{HPO} 4\right)$, magnesium sulfat heptahidrat $\left(\mathrm{MgSO}_{4} .7 \mathrm{H}_{2} \mathrm{O}\right)$, kalsium klorida dihidrat $\left(\mathrm{CaCl}_{2} \cdot 2 \mathrm{H}_{2} \mathrm{O}\right)$, kalium klorida $(\mathrm{KCl})$, yeast ekstrak, fenol, alcohol 70 $\%$, medium natrium agar (NA), reagen folin, dan natrium karbonat $\left(\mathrm{Na}_{2} \mathrm{CO}_{3}\right)$ $20 \%$.

\section{Prosedur Kerja}

\section{Isolasi dan Pemurnian}

Isolasi bakteri pendegradasi fenol dilakukan dengan menggunakan metode enrichment culture dengan menggunakan medium Ramsay yang telah ditambahkan dengan fenol 500 ppm, kemudian masing-masing sampel dimasukkan kedalam medium tersebut dan inkubasi pada suhu ruang selama 48 jam pada shaker dengan kecepatan $150 \mathrm{rpm}$. Setelah 48 jam, dipipet sebanyak 5 $\mathrm{mL}$ inokulum dan dimasukkan dalam $20 \mathrm{~mL}$ media Ramsay segar, kemudian dishaker kembali selama 48 jam dengan kecepatan $150 \mathrm{rpm}$. Pengerjaan ini dilakukan sampai 3 kali pemindahan inokulum ke media Ramsay segar. Pada akhir inkubasi diambil $1 \mathrm{ml}$ dituangkan secara pour plate pada medium Ramsay agar yang telah diperkaya dengan fenol 500 ppm dan diinkubasi suhu ruang dalam incubator sampai terdapat koloni bakteri yang tumbuh. Koloni yang tumbuh dipilih 2 dari masing - masing bak yang terdapat koloni bakteri pendegradasi fenol secara acak. Kemudian dilakukan pemurnian dengan menggunakan medium NA (Nutrient Agar) (Juwita, 2014).

\section{Identifikasi Bakteri}

Identifikasi bakteri yang dilakukan meliputi uji pewarnaan gram, uji biokimia seperti uji produksi $\mathrm{H}_{2} \mathrm{~S}$, uji SIM, uji MR, uji Sitrat, uji urea, uji fermentasi glukosa, laktosa, sukrosa dan manitol.

\section{Uji Kemampuan Degradasi Fenol}

Uji kemampuan degradasi fenol dilakukan dengan cara mengambil 3 ose bakteri pendegradasi fenol kemudian diinokulasikan pada medium ramsay dengan konsentrasi fenol 500 ppm. Dishaker selama 48 jam pada suhu ruang dan kemudian diamati kadar fenol yang masih terkandung didalamnya dengan menggunakan metode folin-ciocalteau dengan menggunakan fenol sebagai standar dengan konsentrasi 2 ppm, 4 ppm, 6 ppm, 8 ppm, dan 10 ppm. Diperiksa pada absorbansi sampel pada $750 \mathrm{~nm}$ menggunakan spektrofotometer UV-VIS (Juwita, 2014). 
Fitriana, Maswati Baharuddin, dan Sappe Wali Isolasi dan Identifikasi Bakteri Pendegradasi Fenol yang Bersumber dari Danau Tempe Kabupaten Wajo Sulawesi Selatan

\section{HASIL DAN PEMBAHASAN}

\section{Isolasi dan Pemurnian}

Sampel air yang berasal dari Danau Tempe Kab. Wajo diperoleh dari bagian Hulu (H), Tengah (C) dan Sungai (S) ditumbuhkan dalam medium sederhana Ramsay dengan penambahan fenol $500 \mathrm{ppm}$. Masing-masing isolat tersebut mampu tumbuh pada media yang mengandung fenol. Tahap awal yang dilakukan pada penelitian ini yaitu isolasi bakteri. Isolasi bakteri merupakan proses pengambilan bakteri dari medium atau lingkungan asalnya dan menumbuhkan pada medium buatan sehingga diperoleh kultur murni atau biakan murni hasil isolasi. Media yang digunakan adalah media Ramsay yang diperkaya dengan fenol 500 ppm dan diharapkan bakteri mampu tumbuh pada media tersebut. Isolasi dilakukan dengan memasukkan $10 \mathrm{~mL}$ sampel air Danau Tempe kedalam media Ramsay yang mengandung fenol 500 ppm kemudian diinkubasi dalam shaker incubator selama 48 jam dengan kecepatan $150 \mathrm{rpm}$. Isolasi dan pemurnian bakteri dilakukan secara aseptik, dimana semua alat-alat gelas dan medium pertumbuhan yang akan digunakan disterilisasi terlebih dahulu agar semua mikroba termasuk spora mati dan tidak menjadi parasit pada media isolasi bakteri yang diinginkan.

Dari hasil inkubasi, masing-masing inokulum dituang secara pour plate ke dalam cawan petri yang telah berisi media ramsay agar dan diperkaya dengan fenol 500 ppm yang digunakan untuk mengamati pertumbuhan bakteri. Fenol digunakan sebagai sumber karbon untuk pertumbuhan bakteri, sehingga hanya bakteri yang mampu memanfaatkan fenol sebagai sumber nutrisi tunggal yang dapat tumbuh (Juwita, 2014).

Masing-masing cawan petri dipilih 2 koloni berbeda dan dimurnikan menggunakan media NA (Nutrient Agar). Media NA merupakan media umum yang sering digunakan pada saat peremajaan bakteri. Kandungan media NA berupa pepton, yeast ekstrak dan agar yang merupakan sumber nutrisi bagi mikroba (bakteri). Dari hasil isolasi diperoleh 6 isolat murni, yaitu: $\mathrm{H}_{1} \mathrm{~F}, \mathrm{H}_{2} \mathrm{~F}$, $\mathrm{C}_{1} \mathrm{~F}, \mathrm{C}_{2} \mathrm{~F}, \mathrm{~S}_{1} \mathrm{~F}$, dan $\mathrm{S}_{2} \mathrm{~F}$ dan dipilih 3 isolat, yaitu isolat $\mathrm{C}_{1} \mathrm{~F}, \mathrm{H}_{2} \mathrm{~F}$ dan $\mathrm{S}_{1} \mathrm{~F}$ untuk dilakukan uji degradasi fenol karena memiliki pertumbuhan yang baik diantara ke-6 isolat tersebut.

\section{Identifikasi Bakteri}

\section{Uji pewarnaan gram}

Uji pewarnaan gram dilakukan untuk mengetahui apakah bakteri yang telah diisolasi merupakan bakteri gram negative atau bakteri gram positif. Bakteri yang telah murni dilakukan uji pewarnaan gram di Laboratorium Mikrobiologi Universitas Hasanuddin Makassar. Dari hasil pewarnaan gram 
diketahui bahwa bakteri yang telah diisolasi merupakan bakteri gram negatif yang berwarna merah, berbentuk coco basillus dan basillus (batang) setelah diamati di bawah mikroskop.

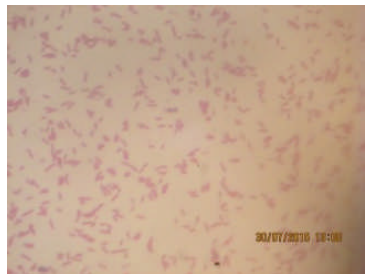

$\mathbf{C}_{1} \mathbf{F}$

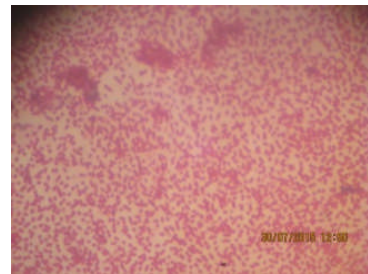

$\mathbf{H}_{2} \mathbf{F}$

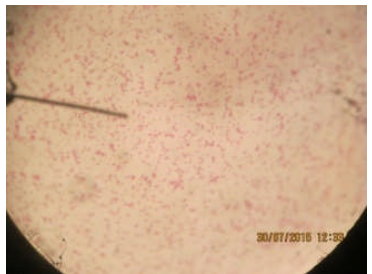

$\mathrm{S}_{1} \mathbf{F}$

Gambar 1. Hasil Uji Pewarnaan Gram

\section{Uji biokimia}

Uji biokimia didasarkan pada berbagai hasil metabolisme yang disebabkan oleh daya kerja enzim (Lay, 1994). Ada beberapa uji biokimia yang dilakukan untuk mengidentifikasi jenis bakteri yang diisolasi, yaitu uji pembentukan $\mathrm{H}_{2} \mathrm{~S}$, uji MR-VP (Methyle Red-Voges Proskauer), uji sitrat, uji urea, uji SIM, dan uji fermentasi karbohidrat. Dari masing-masing uji biokimia yang dilakukan, diperoleh hasil seperti pada tabel di bawah ini:

Tabel 1. Hasil Uji Biokimia Isolat Bakteri

\begin{tabular}{|l|c|c|c|}
\hline \multicolumn{1}{|c|}{ Uji } & IsolatC1F & Isolat S1F & $\begin{array}{c}\text { Isolat } \\
\text { H2F }\end{array}$ \\
\hline TSIA & & & \\
-slant & Acid & Acid/Alkali & Acid \\
-butt & Acid & Acid & Acid \\
$-\mathrm{H}_{2} \mathrm{~S}$ & - & - & - \\
-Gas & + & + & + \\
\hline SIM & & & - \\
-indol & - & - & - \\
- & - & - & - \\
motilitas & - & + & + \\
-H $2 \mathrm{~S}$ & & & - \\
\hline MR & + & + & - \\
\hline Citrat & + & + & + \\
\hline Urea & + & + & + \\
\hline Glukosa & + & + & + \\
\hline Laktosa & + & - & \\
\hline
\end{tabular}


Fitriana, Maswati Baharuddin, dan Sappe Wali Isolasi dan Identifikgasi Bakteri Pendegradasi Fenol yang Bersumber dari Danau Tempe Kabupaten Wajo Sulawesi Selatan

\begin{tabular}{|l|c|c|c|}
\hline Sukrosa & + & + & + \\
\hline Manitol & + & + & + \\
\hline
\end{tabular}

Berdasarkan hasil pengujian yang telah dilakukan dan telah dicocokkan dengan buku database Bergey's Manual of Determinative Bacteriologydapat diketahui bahwa isolat bakteri $\mathrm{H}_{1} \mathrm{~F}$ dan $\mathrm{S}_{1} \mathrm{~F}$ adalah bakteri Enterobacter agglomerans, $\mathrm{H}_{2} \mathrm{~F}$ adalah bakteri Enterobacter hafnia dan $\mathrm{C}_{1} \mathrm{~F}$ dan $\mathrm{S}_{2} \mathrm{~F}$ adalah bakteri Klebsiella spp.

\section{Uji degradasi fenol}

Uji kemampuan degradasi fenol dari 3 isolat bakteri yang terpilih $\left(\mathrm{H}_{2} \mathrm{~F}\right.$, $\mathrm{S}_{1} \mathrm{~F}$ dan $\mathrm{C}_{1} \mathrm{~F}$ ) ditentukan dengan menggunakan spektorofotometer $\mathrm{UV}-\mathrm{V}$ is dengan metode folin-ciocalteau. Sebelum dilakukan pengukuran menggunakan spektrofotometer UV-Vis, terlebih dahulu media yang mengandung bakteri disentrifus selama 5 menit denga kecepatan 12.000 rpm agar sel bakteri terpisah dari medianya. Supernatant (filtrat) yang diperoleh kemudian ditambahkan dengan pereaksi folin sebagai pembentuk kompleks fosfotungstatfosfomolibdat yang berwarna biru. Warna biru yang dihasilkan akan semakin pekat jika konsentrasi fenol yang dioksidasi semakin tinggi.

Pengukuran menggunakan spektrofotometer UV-Vis dilakukan menggunakan larutan standar dengan konsentrasi beragam. Larutan standar dibuat dengan menggunakan larutan induk fenol 1000 ppm yang diencerkan menjadi 2 ppm, 4 ppm, 6 ppm, 8 ppm dan 10 ppm. Pengukuran larutan standar dan sampel menggunakan panjang gelombang $750 \mathrm{~nm}$. Dari hasil pengukuran, dapat dilihat bahwa isolat yang mampu mendegradasi fenol paling banyak adalah isolat $\mathrm{C}_{1} \mathrm{~F}$ yang mampu menurunkan kadar fenol hingga $3.1 \mathrm{ppm}$ dari konsentrasi awal fenol $500 \mathrm{ppm}$. Isolat $\mathrm{S}_{1} \mathrm{~F}$ mampu mengurai fenol menjadi 5.1 ppm dan isolat $\mathrm{H}_{2} \mathrm{~F}$ mampu mengurai fenol menjadi 7.8 ppm selama 48 jam.

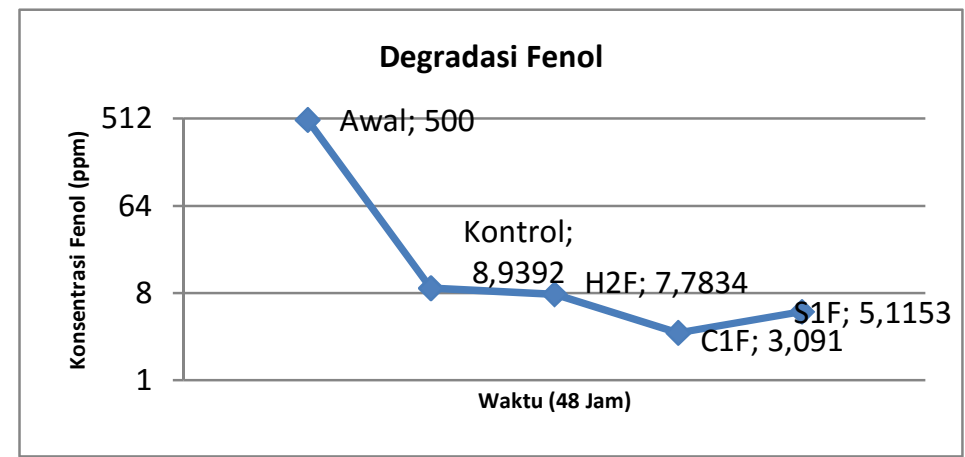

Gambar 2. Kemampuan Degradasi Fenol oleh Isolat Bakteri pada Medium Ramsay dengan Kadar Awal 500 ppm pada Inkubasi 48 Jam 
Fitriana, Maswati Baharuddin, dan Sappe Wali Isolasi dan Identifikasi Bakteri Pendegradasi Fenol yang Bersumber dari Danau Tempe Kabupaten Wajo Sulawesi Selatan

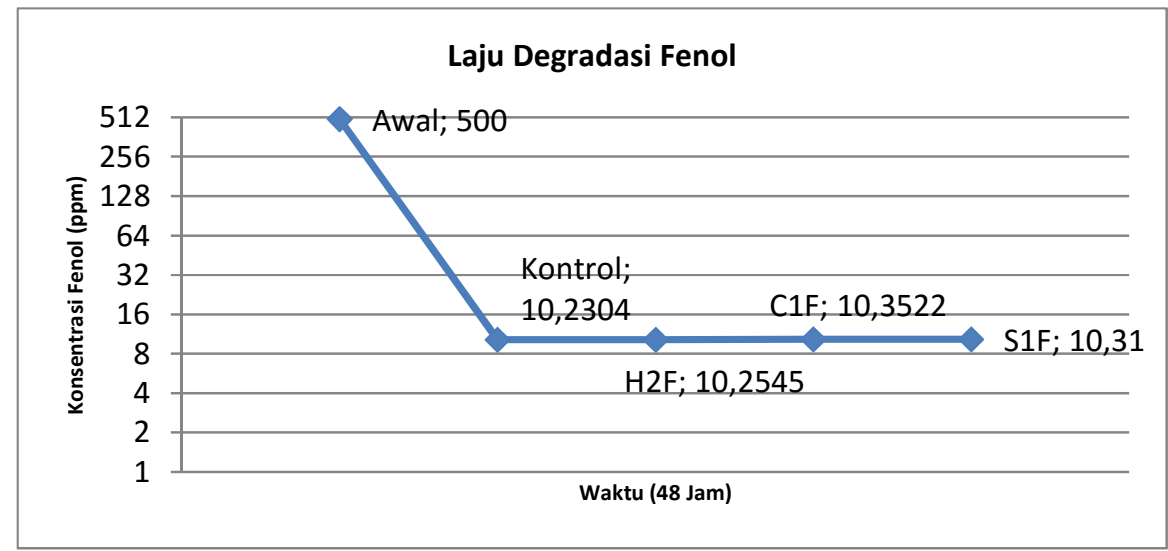

Gambar 3. Laju Degradasi Fenol oleh Isolat Bakteri pada Medium Ramsaydengan Kadar Awal 500 ppm pada Inkubasi 48 Jam

Gambar 2 dan 3 menunjukkan kemampuan masing-masing isolat mendegradasi fenol dengan konsentrasi awal 500 ppm dalam masa inkubasi 48 jam. Dari gambar dapat diketahui bahwa isolat $\mathrm{C}_{1} \mathrm{~F}$ dapat mendegradasi fenol hingga konsentrasi $3.1 \mathrm{ppm}$ di akhir inkubasi dan isolat $\mathrm{C}_{1} \mathrm{~F}$ memiliki laju degradasi paling tinggi, yaitu 10.3522 di akhir inkubasi, sedangkan isolat $\mathrm{H}_{2}$ Fmemiliki kemampuan degradasi paling rendah yaitu hingga $7.1 \mathrm{ppm}$ di akhir inkubasi.

Berdasarkan hasil penelitian Juwita (2014), dari 6 isolat bakteri yang terpilih dilakukan uji degradasi fenol. Kadar awal fenol yang digunakan adalah $500 \mathrm{ppm}$. Dari penelitian yang telah dilakukan, diperoleh isolat yang mampu mendegradasi fenol hingga 23,1428 ppm. Kafilzade, dkk. (2010, h. 6723), berhasil mengisolasi 9 jenis isolat bakteri yang mampu mendegradasi fenol dan salah satunya adalah genus Klebsiella spp. dan genus Enterobacter sp. Berdasarkan hasil penelitiannya, isolat bakteri mencapai pertumbuhan maksimalnya di waktu 24 jam dengan konsentrasi fenol sisa 0,2-0,05 g/L dan setelah 48 jam fenol telah habis terdegradasi.

Biodegradasi merupakan penguraian atau perombakan suatu senyawa dengan memanfaatkan mikroorganisme. Menurut Juwita (2014), Senyawa organik memiliki sifat yang lebih cepat terdegradasi dibandingkan senyawa anorganik. Proses biodegradasi berlangsung secara enzimatis dan bakteri menyerap molekul dengan bantuan enzim hidrolitik. Bakteri dapat menggunakan senyawa hidrokarbon secara utuh maupun sebagian untuk diuraikan secara sempurna. Selama proses inkubasi, media kontrol juga mengalami penurunan konsentrasi fenol. Hal ini disebabkan karena adanya 
proses aerasi yang disebabkan oleh shaker. Terjadinya aerasi merupakan cara manual dalam mengurangi kadar fenol.

Gambar 3 memperlihatkan laju degradasi tiap isolat, dimana laju degradasi yang paling tinggi diperlihatkan oleh isolat $\mathrm{C}_{1} \mathrm{~F}$. Besarnya laju degradasi ditentukan oleh banyaknya konsentrasi sel. Dari hasil penelitian Dewilda (2012), laju degradasi di hari kedua lebih besar dibandingkan hari pertama. Hal ini disebabkan karena biakan bakteri dari fase eksponensial menuju fase stasioner yang memanfaatkan fenol sebagai sumber nutrisi sehingga laju degradasi fenol pada hari kedua lebih tinggi jika dibandingkan pada hari pertama. Menurut Akmal (2010), laju degradasi dipengaruhi oleh konsentrasi sel. Semakin besar konsentrasi sel yang dihasilkan, maka laju degradasi fenol yang dihasilkan juga semakin besar.

Kemampuan bakteri dalam mendegradasi fenol sangat ditentukan oleh lama inkubasi, jenis bakteri dan konsentrasi fenol yang diberikan. Nweke dan Okpokwasili (2014), mengisolasi bakteri dari genus Pseudomonas dengan penambahan fenol sebagai sumber karbon tunggal dengan beragam konsentrasi hingga 1000 ppm. Bakteri Pseudomonas membutuhkan waktu hingga 288 jam untuk mendegradasi fenol 1000 ppm hingga 100\%. Sedangkan fenol dengan konsentrasi rendah $(20 \mathrm{mg} / \mathrm{L})$ dapat didegradasi hanya dalam waktu 3 jam.

\section{PENUTUP}

\section{Kesimpulan}

Berdasarkan hasil penelitian dapat disimpulkan bahwa :

1. Terdapat 3 isolat bakteri dari Danau Tempe yang dapat mendegradasi fenol, yaitu isolat $\mathrm{C}_{1} \mathrm{~F}, \mathrm{H}_{2} \mathrm{~F}$ dan $\mathrm{S}_{1} \mathrm{~F}$.

2. Bakteri yang dapat mendegradasi fenol adalah bakteri dari genus Enterobacter spp dan Klebsiella spp.

\section{Saran}

Saran pada penelitian ini adalah sebagai berikut:

1. Perlunya diadakan penelitian lanjutan terhadap kemampuan degradasi fenol oleh bakteri dengan pengaruh perbedaan konsentrasi dan waktu inkubasi.

2. Penelitian lanjutan pengaplikasian kemampuan degradasi fenol bakteri Enterobacter spp dan Klebsiella spp terhadap limbah yang mengandung fenol. 
Fitriana, Maswati Baharuddin, dan Sappe Wali Isolasi dan Identifikasi Bakteri Pendegradasi Fenol yang Bersumber dari Danau Tempe Kabupaten Wajo Sulawesi Selatan

\section{DAFTAR PUSTAKA}

Ulya, Amaliyatul, 2012, Pengaruh Variasi pH dan Suhu Terhadap Kemampuan Degradasi Fenol dan Pertumbuhan Bakteri Pendegradasi Fenol dari Limbah Cair Tekstil,Skripsi, Yogyakarta: Fakultas Sains dan Teknologi Universitas Negeri Sunan Kalijaga.

Akmal, 2010, Biodegradasi Fenol Limbah Cair Industri Tekstil Oleh Candida tropicalisI,Skripsi, Bogor: Fakultas Matematika dan Ilmu Pengetahuan Alam Institut Pertanian Bogor.

Dewilda, Yommi. 2010, Degradasi Senyawa Fenol Oleh Mikroorganisme Laut,Jurnal Teknik Lingkungan UNAND, 9(1): 59-73.

Juwita, Rahmy, 2014,Isolasi dan Karakterisasi Bakteri Pendegradasi Fenol dari Limbah Cair Rumah Sakit Umum Daerah (RSUD) Arifin Achmad Pekanbaru,JOM FMIPA, 1(2): 229-237.

Kementrian Lingkungan Hidup Republik Indonesia,Profil 15 Danau Prioritas Nasional, Kementrian Lingkungan Hidup, 2011.

Khafilzadeh, Farshid, 2010,Isolation and Identification of Phenol Degrading Bacteria from Lake Parishan and Their Growth Kinetic Assay,Africa Journal of Biotechnology, 9(40): 6723.

Lay, W., Bibiana, 1994,Analisis Mikroba di Laboratorium, Jakarta: PT Raja Grafindo Persada.

Milasari, Ika Nurita, dan Sukma Budi Ariyani, 2010, Pengolahan Limbah Cair Kadar COD dan Fenol Tinggi dengan Proses Anaerob dan Pengaruh Mikronutrient $\mathrm{Cu}$ : Kasus Limbah Industri Jamu Tradisional,Skripsi,Semarang: Fakultas Teknik Universitas Diponegoro.

Nurbaeti, Hajroh, 2014,Isolasi dan Identifikasi Bakteri Toleran Terhadap Fenol dari Limbah Cair Industri Batik Rumahan,Skripsi, Purwokerto: Fakultas Keguruan dan ilmu Pendidikan Universitas Muhammadiyah Purwokerto.

Nweke, C.O., Okpokwasili G.C., 2014, Kinetics of Growth and Phenol Degradation by Pseudomonas species Isolated from Petroleum Refinery Wastewater,Internation Journal of Bioscience, 4(7): 28-37.

Yuliastuti, Etik, 2011, Kajian Kualitas Air Sungai Ngringo Karanganyar dalam Upaya Pengendalian Pencemar Air,Thesis, Semarang: Program Pasca Sarjana Universitas Diponegoro. 